\title{
Lionello Sozzi, «Pavese: da Balzac a Proust», in Cesare Pavese, atti del Convegno internazionale di studi
}

Marco Stupazzoni

\section{(2) OpenEdition} Journals

Edizione digitale

URL: https://journals.openedition.org/studifrancesi/26502

DOI: $10.4000 /$ studifrancesi.26502

ISSN: 2421-5856

\section{Editore}

Rosenberg \& Sellier

\section{Edizione cartacea}

Data di pubblicazione: 1 avril 2007

Paginazione: 192

ISSN: 0039-2944

\section{Notizia bibliografica digitale}

Marco Stupazzoni, «Lionello Sozzi, «Pavese: da Balzac a Proust», in Cesare Pavese, atti del Convegno internazionale di studi», Studi Francesi [Online], 151 (LI | I) | 2007, online dal 30 novembre 2015, consultato il 23 novembre 2021. URL: http://journals.openedition.org/studifrancesi/26502 ; DOl: https://doi.org/10.4000/studifrancesi.26502

Questo documento è stato generato automaticamente il 23 novembre 2021.

\section{cc) (†) $\odot$}

Studi Francesi è distribuita con Licenza Creative Commons Attribuzione - Non commerciale - Non opere derivate 4.0 Internazionale. 


\title{
Lionello Sozzi, «Pavese: da Balzac a Proust», in Cesare Pavese, atti del Convegno internazionale di studi
}

\author{
Marco Stupazzoni
}

\section{NOTIZIA}

LIONELlo SozzI, «Pavese: da Balzac a Proust», in Cesare Pavese, atti del Convegno internazionale di studi, Torino-Santo Stefano Belbo, 24-27 ottobre 2001, a cura di Margherita CAMPANELlo, Firenze, Leo Olschki, «Università di Torino. Centro di studi di letteratura italiana in Piemonte " Guido Gozzano-Cesare Pavese "», 2005, vol. 16 saggi, pp. 43-54.

1 Da Balzac... a Proust passando per Stendhal e Flaubert e per alcuni scrittori anglosassoni, il cammino della riflessione critica di Cesare Pavese sul romanzo non esita certo a «richiamarsi a punti di riferimento a tutti noti $\mathrm{e}$ in qualche modo esemplari» (p.43). Tra le pagine dei Saggi letterari (1951) o in quelle de Il Mestiere di vivere (Diario 1935-1959) del 1952, numerosi sono i riferimenti ai "grandi classici" della letteratura europea che, in questo studio, Lionello Sozzi porta alla luce ricomponendoli in un prezioso mosaico ricco di multicolori sfumature letterarie e di suggestive implicazioni estetiche. Nel caso di Balzac, ad esempio, Pavese assume posizioni critiche che, precorrendo i tempi futuri, pongono come chiave di volta della sua poetica romanzesca la curiositas, ovvero quel particolare modo di porsi nei confronti del reale che, ricorrendo ad una scrittura simbolica, apre la scrittura stessa alla «proposta di un mistero da indagare, di un dubbio da sciographie» (p. 45). Nessuna trascrizione del reale, in Balzac, ma «una sorta di apparente ingenuità, la capacità, cioè [...] di creare l'illusione che il mondo inventato sia la vita» (p. 46). 